\title{
ВОЄННО-ПОЛЬОВА ТЕРАПІЯ ЧИ ВІЙСЬКОВА ТЕРАПІЯ, ВОЄННО-ПОЛЬОВА ХІРУРГІЯ ЧИ ВІЙСЬКОВА ХІРУРГІЯ?
}

\author{
М.П. Бойчак \\ Українська військово-медична академія (м. Київ)
}

Вступ. У статті в дискусійній формі розглядається питання щодо назв кафедр військової терапії і військової хірургії Української військово-медичної академії та відповідних дисциплін, що вивчаються на цих кафедрах. В історичному аспекті досліджується еволюція поглядів щодо цих назв (воєнно-польова хірургія - військова хірургія, воєнно-польова терапія - військова терапія), починаючи від М.I. Пирогова, B.A. Оппеля, С.С. Юдіна, закінчуючи формуванням відповідних кафедр і навчальних дисциплін при організації Української військово-медичної академії.

Мета. Розглянути питання щодо назв кафедр військової терапії і військової хірургії Української військово-медичної академії та відповідних дисциплін, що вивчаються на цих кафедрах.

Матеріали та методи дослідження. В дослідженні використано історичний $і$ бібліосемантичний методи для повного розкриття суті досліджуваних понять.

Результати дослідження. Обидва терміни «Воєнно-польова терапія» $i$ «Військова терапія» мають право на існування, використовувались у різні часи по різному. Як на нас, то більш правильно, сьогодні, з огляду назви кафедри і назви дисципліни, використовувати термін «Військова терапія», адже на кафедрі, крім класичної воєнно-польової терапії (ураження іонізуючим випромінюванням, ураження отруйними речовинами, біологічними чинниками тощо) вивчаються ще багато інших дисциплін: 24 дисципліни для слухачів факультету підготовки військових лікарів; 23 дисципліни для факультету перепідготовки та підвищення кваліфікації (спеціалізація, тематичне вдосконалення, до 2020 року передатестаційні цикли) та 12 дисциплін для медичних сестер (спеціалізація, тематичне вдосконалення). Крім військових дисциплін на кафедрі ВТ викладаються «мирні» дисципліни: кардіологія, пульмонологія, гастроентерологія, гематологія, ревматологія, психіатрія і наркологія, психотерапія, фізіотерапія, лабораторна діагностика, функціональна діагностика тощо. Тобто термін «Військова терапія» має більш широке тлумачення ніж термін «Воєнно-польова терапія».

Висновки. Підсумовуючи розглянуте питання, треба надати належне керівникам військової медицини, які при формуванні Військово-медичного відділення при Українському державному медичному університеті імені О.О. Богомольия (пізніше УВМА) і профільних кафедр, назвали їх відповідно кафедрами військової хірургії і військової терапії. Якщо словосполучення «воєнно-польова» було вже застарілим для B.A. Оппеля і С.С. Юдіна майже 100 років назад, якщо М.I. Пирогов, який запропонував цей термін, сам його не вживав, якщо головний терапет Червоної армії М.С. Вовсі, головні терапевти фронтів, армійські терапевти Другої світової війни майже не користувалися ним, якщо засновник російської клінічної медицини М.Я. Мудров майже 300 років назад говорив про «військову терапію», а наш видатний земляк $A$. Чаруковський тоді ж говорив про «хвороби армії», а як нам бути з майбутніми партнерами по НАТО, якщо у них, та взагалі ніде у світі, більше не викорисовується термін «воєнно-польова» і не має воєнно-польової хірургії та воєнно-польової терапії, крім деяких бувших республік СРСР та країн його сателітів, які його собі присвоїли та «зрадянщили», то чи стоїть нам повертатись до колишніх назв, та дисциплін, які не існують? А своє захоплення генієм M.I. Пирогова і повагу до його особистості будемо виражати не у збережені терміну «воєнно-польова», а в іншому - у подальшому розвитку військової хірургії і військової mepaniï.

Ключові слова: воєнно-польова-хірургія, воєнно-польова терапія, військова хірургія, військова терапія, Українська військово-медична академія.

Вступ. Коли у 1993 р. була організована Українська військово-медична академія (УВМА) і постали кафедри військової терапії, військової хірургії та інші, то назва кафедр без звичного «польова», якось сприймалось незвично. У багатьох виникали запитання: чому «військова терапія», а не «воєнно-польова терапія», чому «військова хірургія», а не всім знайома «воєннопольова хірургія»?

Проте ніхто і не задавався питанням - чому така назва. Усі були раді, що Академія взагалі у нас появилася. Мабуть перша думка була - назвали так, аби не повторювати радянської назви. У всякому разі автор статті для себе пояснив саме так. Але коли за плечима навчання на трьох кафедрах воєнно-польової терапії (Саратов, Москва, Ленінград), коли зі студентських років у пам'яті підручники і посібники з воєнно-польової терапії (М.С. Молчанова, 
Ф.І. Комарова, Є.В. Гембіцького та інших), коли не раз приходилось у полі, будучи головним терапевтом Забайкальського військового округу, розгортати військово-польовий терапевтичний госпіталь чи інші «військово-польові» госпіталі, то питання все рівно десь залишалося. На запитання до ветеранів, які стояли у витоків створення Академії, чіткої відповіді так і не отримав. 3 часом у нас появилися підручники не з воєнно-польової терапії, а 3 військової терапії $(2004,2007)$, не з воєнно-польової хірургії, а з військової хірургії (2004). Аналогічна ситуація спостерігалася і з іншими навчальними дисциплінами Академії. Слово «польова» у них теж десь загубилося.

Через 25 років існування Академії, чи то перед ювілеєм, чи то за того, що продовжувалася війна на Сході України, стали появлятись відповідні керівництва з фахових дисциплін та підручники: вже не з військової хірургії, а з воєнно-польової хірургії $(2014,2016$, 2018), не з військової терапії, а з воєнно-польової терапії $(2015,2017)$. І знову постало питання: так якою, все таки, має бути правильною назва наших кафедр та відповідних дисциплін? Чому через 25 років існування кафедр військової хірургії та військової терапії ми починаємо писати підручники з воєнно-польової хірургії і воєнно-польової терапії?

Мета дослідження. Розглянути питання щодо назв кафедр військової терапії i військової хірургії Української військово-медичної академії та відповідних дисциплін, що вивчаються на цих кафедрах.

Матеріали та методи дослідження. В дослідженні використано історичний i бібліосемантичний методи для повного розкриття суті досліджуваних понять.

Результати дослідження та їх обговорення. Аби відповісти на це запитання повернімося до його історії. Першим хто написав словосполучення «воєннопольова» був М.I. Пирогов, видавши у 1865 р. «Начала общей военнополевой хирургии». Правда раніше, у 1864 p. німецькою мовою, вийшла майже та сама книга тільки 3 іншою назвою «Grundzuge der allgemeinen Kriegschirurgie» («Начала общей военной хирургии»). Первоначальна німецька «військова хірургія» була замінена на російську «воєннопольову хірургію».

Останню назву Микола Іванович пояснював наступним: «Я назвал мою книгу военнополевою хирургиею, потому что в ней говорится только о предметах, занимающих военного врача в военное время» [1]. Звернемо увагу, що автор книги назвав «воєнно-польову хірургію» як предмет для військового лікаря тільки на військовий час, але навіть у своїй книзі він більше не звертався до терміну «воєнно-польова хірургія», називаючи цей предмет «військовою хірургією» (ч.1, с. 6) або «польовою хірургією» (ч.1, с. 41), а лікарів, які нею займались називав не «воєнно-польовими хірургами», а «військовими хірургами» (ч.1, с. 60, 76; ч.2, с. $58,144,163,173,190$ ) чи «польовими хірургами». Тобто, назва дисципліни (розділу хірургії) у М.І.Пирогова міститься тільки у назві книги, давши назву предмету у заголовку книги, а потім по тексту більше ним не користувався.

Частіше всього, описуючи надання хірургічної допомоги на війні М.І.Пирогов користувався звичайними термінами: «хірург», «хірургія», без добавляння слів «військовий» чи «польовий». Лише у 7 главі (ч. 2) - «Военно-полевые хирургические операции», М.І. Пирогов користується терміном «воєнно-польовий хірург» і «воєнно-польова хірургія». Часто вживав термін «воєнно-польова практика», як синонім «воєнно-польовій хірургії».

Цікаво, що до воєнно-польових хірургічних операцій він відносив всього 5 операцій: 1) Діставання сторонніх тіл з ран і з'єднання ран швом. 2) Операції зупинки кровотечі. 3) Трепанація. 4) Резекція кісток і суглобових кінців. 5) Ампутація і вилущення із суглобів [1].

За два роки до смерті М.I. Пирогов видав книгу «Военно-врачебное дело и частная помощь на театре войны в Болгарии и в тылу действующей армии в 1877-1878 гг.» (1879), у якій підводить підсумки своїй хірургічній діяльності у різних війнах. I в цій праці він теж не користується терміном «воєнно-польова хірургія», називаючи ії «польовою хірургією». У першій главі - «Основные начала моей полевой хирургии», Микола Іванович писав:

«Прошло слишком 30 лет с тех пор, как я, в первый раз, ознакомился с моей полевою хирургиею на небольшом театре войны, и почти 25 лет с того времени, когда я действовал на обширном поприще полевой хирургии... Основы моей полевой, хирургической деятельности я сообщил, только спустя 10 лет, после достопамятной крымской компании... 
Наконец, в минувшую нашу восточную войну 77-78 годов... я имел случай еще более глубоко увериться в прочности основных начал моей полевой хирургии». Далі у цій главі М.I. Пирогов викладає 20 начал своєї польової хірургії.

Прочитавши книгу, ми ніде не зустріли, аби автор говорив про «воєнно-польову хірургію». Мова лише йшла про «польову хірургію» (с. 1, 178, 181, 187, 198, 264, 323, 381), часто вживав терміни: «воєнно-польова практика», «польова госпітальна практика», «воєннопольова госпітальна практика» [2].

Проте, заради справедливості, варто сказати, що М.І. Пирогов не був першим, хто підняв на щит воєнно-польову хірургію та став їі засновником. Витоки військової хірургії губляться у сивій давнині. Оригінально висловився видатний російський (радянський ) хірург С.С. Юдін, зауважуючи, що хірургія народилась 3 військової хірургії, а не навпаки. При цьому згадував прізвище Гіппократа, який був, на його думку, не тільки «великим батьком медицини», але і засновником хірургії, а саме військової хірургії, яка розвивалась під впливом частих війн. Гіппократ стверджував, що «служба в армії - краща школа хірургії» [2].Сам М.I. Пирогов, при всьому його науковому честолюбстві, визнавав «отцами полевой хирургии нашего столетия французских и английских хирургов» і не меньш знаменитих німецьких військових хірургів Г. Штромейера, Б. Лангебека і Ф. Есмарха» [3].

Як наука військова хірургія стала формуватись у Європі у середині 19 ст., чому сприяли континентальні війни та революції. У таких країнах, як Франція та Англія були вже особливі кафедри з військової хірургії, видавались журнали, друкувались звіти з цього предмету. Ось як писав про початок розвитку і розквіту наукової хірургії у Франції завідувач госпітальною хірургічною клінікою Університету Св. Володимира професор Ф.К. Борнгаупт: «Полевой хирург Larrey заседал в военном совете Наполеона наряду с маршалами Франции и завоевал таким образом для медиков подобающее им положение в обществе, полевую же хирургию он поднял до уровня прочих отраслей медицины» [4]. Французьська школа військових хірургів, крім Д. Ларрея була представлена такими особистостями як Ле Дран, Ж. Пті, П. Персі. Крім згаданих нами німецьких хірургів видатними хірургами, які зробили значний внесок у військову хірургію були учень Б. Лангебека Т. Кохер та засновник асептики Е. Бергман.

Росія у середині 19 ст. значно відставала від країн Європи у розвитку військової хірургії. Рада Університету Св. Володимира, розуміючи важливість мати підготовлених військових хірургів для надання медичної допомоги у сучасній війні, вирішила: «Россия, величайшая военная держава Европы, пока еще не имеет подобных учреждений (малась на увазі підготовка військових хірургів - автор) и не участвует в этих стремлениях. Но существующая уже и может быть угрожающая еще большая война потребует опять не только многих, но и специально образованных врачей и в особенности операторов». Для виправлення цього недоліку у підготовці лікарів медичний факультет пропонував запровадити при Університеті нову кафедру оперативної і військової хірургії. Найбільш підготовленим хірургом у цій області був професор-консультант Київського військового госпіталю Ю.К. Шимановський. Рада Університету прийняла рішення доручити новостворену кафедру «профессору Шимановскому, которого труды по части оперативной и военной хирургии пользуются европейской известностью». Заняття 3 військової хірургії у 1863-1864 навчальному році медичний факультет доручив професорам В.А. Караваєву і Ю.К. Шимановському [8]. У 1864-65 pp. Ю.К. Шимановський читав «оперативную хирургию с указанием на военную хирургию по 4 часа в неделю для студентов 7 и 8 семестров...» на базі Київського військового госпіталю [5,6]. Зауважимо, що на цей час ще не вийшли у світ «Начала общей военно-полевой хирургии» M.I. Пирогова, а його намагання наладити викладання військової хірургії у Медико-хірургічній академії залишались без результатів. Тільки у 1869 р. у цій Академії було започатковано викладання польової хірургії для військових лікарів у вигляді спеціальних курсів [7].

Не подобалась назва «воєнно-польова хірургія» і одному 3 видатних російських (радянських) воєнно-польових хірургів В.А. Оппелю, який у 1931-1932 рр. очолював однойменну кафедру Військово-медичної академії. У своїй книзі «История русской хирургии» (1923) він писав: 
«Название «военно-полевая хирургия укоренилось. А между тем лично мне кажется, что это название какое-то устарелое, не вполне совпадающее с предметом, им обозначаемым. Понятно, что хирургическая деятельность во время войны вовсе не обязательно связана с работой «в поле», в разбитых шатрах. Военно-полевой госпиталь правильно носит свое название, ибо он развертывается в шатрах и в поле. Но хирургическая деятельность во время войны протекает в таких различных условиях: и на станциях жел. дорог, и в домах различных деревень, и в городских домах, и в специальных больничных учреждениях, что характеризовать эту деятельность по возможному ее проявлению и в поле в развернутых шатрах, мне бы казалось, не совсем правильно. Из существующих иностранных названий немецкое «Kriegschirurgie» наиболее отвечает своей цели, охватывая в названии всяческие возможности хирургической работы во время войны, характеризуя особенность хирургии не местом работы, а ее характером. Вот почему мне представляется более правильным и на русском языке говорить о «хирургии войны», вместо «военно-полевой хирургии»... Пирогов в свое время был большой поклонник работы в госпитальных палатках. Он неоднократно отмечал, что в палатках послеоперационный период раненых протекает неизмеримо лучше, чем в зданиях... для Пирогова поэтому название «военно-полевая хирургия», даже просто «полевая хирургия» имело свой смысл, подчеркивающий стремление подавать помощь раненым именно в поле, в госпитальных шатрах. Для нашего времени это не имеет никакого значения. Если и в наше время можно отлично оборудовать операционную в госпитальной палатке, если в наше время можно расположить раненых также в госпитальных шатрах, то это не обязательно, это не характерно для хирургии войны. Поэтому, еще раз повторяю, лично я предпочитаю название «хирургия войны» [8].

Сам В.А. Оппель називав воєнно-польову хірургію хірургією війни і свою основну книгу присвячену наданню хірургічної допомоги на війні назвав «Очерки хирургии войны», яка вийшла вже після його смерті у 1940 році.

У цій книзі він ще раз пише, що відмовився від назви «воєнно-польова хірургія», або, як іï називав ще М.І. Пирогов «польова хірургія», надавши перевагу назві «хірургія війни». Польова хірургія, тобто хірургія, яка надає допомогу пораненим на полі бою, маючи на увазі передові етапи надання хірургічної допомоги, $є$ і сьогодні, але, за переконанням В.А. Оппеля, вона $\epsilon$ тільки складовою всієї хірургії війни. Надання хірургічної допомоги на всіх наступних етапах евакуації (район головних, тилових евакуаційних пунктів, тил країни) він відносив до звичайної хірургії, або хірургії війни:

«Военно-полевая хирургия представляет собой лишь часть хирургии войны. Военнополевая хирургия сама превращается в хирургию передового хирургического пояса действующей армии, а в этом поясе помощь раненым также стараются подавать не в поле, а в каком-нибудь селении, станции, городке, где можно было найти приют для раненых и помещение для развертывания перевязочной и операционной. Работа в поле, в шатрах, и сейчас может оказаться нужной, полезной, единственно возможной, и в шатрах помощь необходимо разворачивать сообразно с требованиями современной хирургии. На эвакуационных пунктах, в их госпиталях, помощь уже оказывается обычно в зданиях, причем под госпитали обычно отводятся лучшие или одни из лучших зданий, имеющихся в данном месте. Борьба с инфекцией не есть задача «полевой» хирургии. В компетенцию последней входит предупреждение заражения ран, а само лечение инфицированных ран должно проводиться в более удаленных от линии огня учреждениях, на эвакуационных пунктах. Долечивание раненых идет в еще более тыловых хирургических учреждениях. Долечивание, восстановление трудоспособности раненых - задача довольно трудная. Она осуществляется хирургией войны, но никоим образом не «полевой» [9].

Не підтримував назву військової хірургії як «воєнно-польова» хірургія і видатний російський (радянський) хірург С.С. Юдін: «Полевая война ушла в прошлое и, может быть, приставка «полевой» устарела для современной военной хирургии. Мы сохраняем ее лишь как маленький штрих благоговейного уважения к памяти и терминологии величайшего из хирургов родной страны» (с. 3). Саме тому, за поваги до М.І. Пирогова, Сергій Сергійович назвав свою книгу (збірник праць різних авторів за його редакцією - автор) - «Заметки по военно- 
полевой хирургии», а не з військової хірургії. Аби пояснити свою думку, він пише: «Название нашего сборника может вызвать раздумье. Ушли те времена, когда воюющие армии сражались в чистом поле, концентрируя свои силы на глазах друг у друга. Решающие схватки ныне разыгрываются иначе. Противник действует под водой, в небесных просторах над землей, в бетонных казематах сложнейших инженерных сооружений внутри земли, в лабиринтах асфальтированных улиц многомиллионных европейских столиц и вокруг железнодорожных мостов и плотин, атакованных за сотни километров парашютными десантами или быстроходными танками. Гудит небо от вихря тысяч пропеллеров; разверзается чрево земли от взрывов двухтонных бомб; рушатся столетние стены грандиозных зданий - памятников многовековой культуры».

Цією сентенцією С.С. Юдін якби підводить нас до думки, що це вже не військово-польова хірургія. Адже в таких умовах не можливо надавати хірургічну допомогу в полі, тобто в умовах наближених до описаного ним аду, вона має надаватись дальше від нього, в інших умовах. А ті умови мають бути наближеними до реальної хірургії, то при чому тут воєнно-польова хірургія?

Але сумніви автора «Заметок» ведуть його дальше. Він ставить питання ще більш радикально: «Существует ли в настоящее время особая военная хирургия если не как самостоятельная наука, то по крайней мере как специальная отрасль практической хирургии, имеющая свою медицинскую специфику? Вопрос этот - вовсе не теоретический».

Дальше С.С. Юдін аналізує проблеми хірургії взагалі, і на їх фоні пробує вияснити місце і завдання військової хірургії, а на цій основі вирішити питання щодо ії специфіки. Відсилаємо читача безпосередньо до книги автора, зокрема до сторінки, де він вирішує це складне історичне і навіть філософське питання.

Цікавим у цих його роздумах, $є$ те, що С.С. Юдін неочікувано говорить про історичне місце хірургії взагалі і військової хірургії зокрема, про першість, як ми вже згадували вище, в історичному розвитку саме військової хірургії і потім тільки на ії основі розвиток наукової хірургії, чи академічної, як він ії називав:

«Спрос на хирургическую помощь возникал больше всего на время войн. И, как это не парадоксально, благороднейшие задачи хирургии, плоды которой благодетельствовали человечество, ставились и решались главным образом в периоды самых мрачных человеческих исступлений. Вершины человеческих знаний достигались в пору массовых людских безумств... И величайшими создателями современной научной хирургии оказались военные хирурги. Достаточно вспомнить имена Амбруаза Парэ (Ambroise Pare), Ларрея (Larrey), Н.И. Пирогова, Е. Бергмана (Ernst v. Bergmann) и Н.В. Склифосовского. Все они проделали вместе с армиями по нескольку компаний, отдали походной жизни долгие годы, в совершенстве постигли сложную обстановку военно-полевой хирургии и сумели добыть драгоценные сведения, укрепляющие и продвигающие вперед нашу хирургическую науку. Все учение о ранах и гнойных процессах веками базировалось на опыте военных хирургов. Хірургія академічна народилась і поступово відокремилась з хірургії військової, а не навпаки» [10].

А що нам відомо з термінологічних визначень відносно «Воєнно-польової терапії» і «Військової терапії»? Щодо «Воєнно-польової терапії» - тут нібито все ясно. Термін запропонував не терапевт, а начальник ГВСУ Червоної армії Ю.I. Смирнов у 1941 році, перед початком Другої світової війни, виступаючи на засіданнях наукових товариств терапевтів Москви і Ленінграду.

Новий термін «Воєнно-польова терапія» не дуже швидко прижився і в перші роки його існування не завжди використовувався. Зокрема, головний терапевт Червоної армії часів Другої світової війни професор, генерал-майор медичної служби М.С. Вовсі частіше вживав термін «військова терапія». Так, у передмові до книги свого заступника професора генералмайора медичної служби П.І. Єгорова «Вопросы военно-полевой терапии», яка вийшла у 1945 році, писав: «Организационные формы и возможности полноценной работы военная терапия приобрела лишь в Красной армии в Великую Отечественную войну. Военная терапия стала неотъемлемой частью медицинской службы армии, приближаясь по значению своему к делу обслуживания раненых и противоэпидемической защите войск. Как всякая новая область военной медицины, военная терапия развивалась, видоизменяла свои лечебные учреждения 
применительно к нуждам полевых войск. Будучи молодой военно-медицинской областью знания, военная терапия еще далеко не разработала основные разделы своей дисциплины, не закончив полностью и свое организационное построение» [11].

Показовим у цьому плані був 13-й Всесоюзний з'їзд терапевтів у Ленінграді 1947 року, в одній із секцій якого підводились підсумки надання медичної допомоги хворим терапевтичного профілю. Головний терапевт, на той час вже Радянської армії, М.С. Вовсі у доповіді «Внутренняя медицина в период Великой отечественной войны 1941-1945 гг.» знову ж таки не користувався терміном «Воєнно-польова терапія». Він говорив про терапевтичну допомогу на війні, про внутрішню медицину в період війни, про нову главу внутрішньої медицини, а терапевтів, які надавали допомогу хворим називав військовими терапевтами [12]. До речі, серед інших делегатів, що виступали на зїзді, цей термін теж рідко використовувася, частіше говорилось про «військову терапію», «внутрішню медицину на війні» чи «терапію на війні». Так, професор С.О. Бадилькес дав наступне визначення військової терапії: «Что такое военная терапия? Военная терапия это появление не только новых заболеваний, ... это не только посттравматические заболевания, это заболевания, протекающие по-иному, в результате изменения реактивности организма» [13]. У резолюції 3'їзду теж не використовувався термін «Воєнно-польова терапія», а мова йшла лише про терапевтичну допомогу на війні.

Трохи пізніше, у 1948 р., М.С. Вовсі, будучи головним терапевтом Радянської армії писав: «Интересы и задачи военно-полевой терапии в условиях действующей армии существенно отличны от объема терапии военной в мирное время» [14]. Тобто, можна розуміти так, що $\epsilon$ «воєнно-польова терапія» на воєнний час і « терапія військова» на мирний час. Про воєннопольову терапію М.С. Вовсі згадав у дусі підготовки до майбутньої війни. Термін «воєннопольова терапія» став широко використовуватись у післявоєнний період, що було пов'язано, по-перше - із повсюдним викладанням предмету «Воєнно-польова терапія» у всіх медичних навчальних закладах країни, організацією однойменних кафедр, появою відповідних підручників, по-друге - 3 початком «холодної війни», загрозою застосування зброї масового знищення.

Якщо поглинути ще глибше в історію питання, то не слід забувати, що один 3 засновників військової терапії (в Росії його згадують як засновника воєнно-польовоїтерапії, хоча таким він не був). М.Я. Мудров ще у 1809 р., виголошуючи знамениту лекцію для студентів медичного факультету Московського університету «Слово о пользе и предметах военной гигиены» говорив, що військова медицина може бути розділена на 4 частини: військова гігієна, військова терапія або армійська клініка, військова або полкова хірургія і польова фармакопея. При цьому він посилався на англійського військового лікаря Монро, який запропонував термін «Військова терапія» ще у 1740 році [15].

Завідувач кафедрою приватної патології і терапії Медико-хірургічної академії К.Ф. Уден, підтримував думку М.Я. Мудрова щодо викладання предмету військової медицини, з 1809 р. сам читав студентам курс військової медицини (предмет «военной гигиены») і наполягав на заснуванні у Медико-хірургічній академії особливої кафедри «Военной медицины», пропонував досвідченим вченим написати керівництво з цього предмету «на пользу врачей военных сухопутных и морских сил» [16].

Не лишнім буде нагадати про нашого видатного земляка військового лікаря Я.О. Чаруківського, який у 1836-37 рр. видав свою знамениту «Воєнно-похідну медицину», розділивши військову медицину на три частини: військову гігієну, медицину і хірургію. Під медициною він розумів власне хвороби в армії і детально розписав, які з них панували на той час в армії [17].

Таким чином, обидва терміни «Воєнно-польова терапія» і «Військова терапія» мають право на існування, використовувались у різні часи по різному. Як на нас, то більш правильно, сьогодні, з огляду назви кафедри і назви дисципліни, використовувати термін «Військова терапія», адже на кафедрі, крім класичної воєнно-польової терапії (ураження іонізуючим випромінюванням, ураження отруйними речовинами, біологічними чинниками тощо) вивчаються ще багато інших дисциплін: 24 дисципліни для слухачів факультету підготовки 
військових лікарів; 23 дисципліни для факультету перепідготовки та підвищення кваліфікації (спеціалізація, тематичне вдосконалення, до 2020 року передатестаційні цикли) та 12 дисциплін для медичних сестер (спеціалізація, тематичне вдосконалення). Крім військових дисциплін на кафедрі ВТ викладаються «мирні» дисципліни: кардіологія, пульмонологія, гастроентерологія, гематологія, ревматологія, психіатрія і наркологія, психотерапія, фізіотерапія, лабораторна діагностика, функціональна діагностика тощо. Тобто термін «Військова терапія» має більш широке тлумачення ніж термін «Воєнно-польова терапія».

Якщо взяти навіть сьогодення, війну на Сході України, то чи є там сьогодні воєннопольові госпіталі? Чи можна назвати нинішніх військових хірургів воєнно-польовими хірургами, а військових терапевтів воєнно-польовими терапевтами?

Давайте подивимось на сучасну систему лікувально-евакуаційних заходів (ЛЕЗ). Якщо ще у кінці 90-х років у ЗС України передбачалася передова госпітальна база з відповідними польовими госпіталями, на рівні корпусу - польовий центр медичного забезпечення 3 польовими пересувними госпіталями, то у сучасній ЛЕЗ взагалі не має польових госпіталів. Медична допомога (хірургічна, терапевтична) в АТО/ООС надається у ВМГ, ВМКЦ, військових госпіталях, центральних районих лікарнях, Дніпропетровській обласній лікарні імені I.I. Мечникова, клінічних закладах НАМН України, тобто у стаціонарних умовах. Навіть у ВМГ, що дислокуються найближче до бойових дій, створенні умови, наближенні до стаціонарних.

Реально у полі сьогодні надається перша медична, долікарська та перша лікарська допомога, яка на разі є дуже важливою, саме від неї залежить структура санітарних втрат, зокрема співвідношення безповоротних і санітарних втрат [18]. Получається, що наші військові і цивільні хірурги сьогодні надають допомогу зовсім не у польових умовах. Більша частина їі приходиться на роботу в умовах ВМКЦ (Київ, Львів, Одеса, Вінниця, Харків), тобто у тих самих умовах, у яких вони працювали і до війни, просто контингент хворих та інтенсивність роботи інші. Навіть умови роботи військових хірургів у ВМГ, на базі ЦРЛ чи міських лікарень, сьогодні мало чим відрізняються від звичайних умов мирного часу. Тож чи правильно буде називати військових хірургів воєнно-польовими хірургами? Те саме можна сказати і про військових терапевтів.

А чи необхідно називати хірургів Дніпропетровської обласної лікарні, які надають допомогу тисячам поранених - воєнно-польовими хірургами? Ми не називаємо їх навіть військовими хірургами, вони $є$ просто хірургами, які надають допомогу пораненим, добре освоїли хірургічну патологію війни, основи військової хірургії, і як результат - чудово з нею справляються. 3 мінно-вибуховими ураженнями, бойовою політравмою раніше ніколи не зустрічались навіть бувалі хірурги лікарні, які по тридцять років у професії. Щой казати про молодих хірургів, які навіть такого предмету в університетах не проходили.

А чи можна було називати воєнно-польовими хірургами тих, які закінчили УВМА i кафедру військової хірургії на початку її заснування, і дослужились за 20 років незалежності України до полковників, ні разу не будучи у «полі», не розгортаючи «воєнно-польових» госпіталів, не оперуючи (хоча би імітуючи) у палатках. Крім кафелю і паркету, затишних кабінетів і палат вони нічого не бачили. Проте їх можна спокійно назвати військовими хірургами, адже вони освоїли особливості хірургічної патології у військовослужбовців, надаючи невідкладну допомогу - працювали в умовах наближених до екстремальних, приймали участь у миротворчих операціях, приймали участь у ліквідації різного роду природних і техногенних катастроф, теоретично освоїли основи класичної військової хірургії та основи організації медичного забезпечення військ, знайомі з хірургією пошкоджень, яка $\epsilon$ науковою і практичною основою розвитку військової хірургії, працювали у суровій армійській систем (згадаємо Гіппократа: «служба в армії - краща школа хірургії») та у специфічній системі військово-медичної служби, яка суттєво відрізняється від цивільної. Те само можна сказати і про військових терапевтів стосовно сфери їх діяльності.

\section{Висновки}

Підсумовуючи розглянуте питання, треба надати належне і тим керівникам військової медицини, які при формуванні Військово-медичного відділення при Українському державному медичному університеті імені О.О. Богомольця (пізніше УВМА) і профільних кафедр, назвали їх 
відповідно кафедрами військової хірургії і військової терапії. Серед них, на нашу думку, слід згадати, на той час полковників медичної слуби В. В. Паська (начальник Військово-медичного відділення, пізніше начальник УВМА), Б.А.Клішевича (заступник начальника Військовомедичного відділення, пізніше його начальник), В.Я. Білого (виконував обов'язки начальника кафедри військової хірургії), М.М. Вовкодава (виконував обов'язки начальника кафедри військової терапії). Варто не забувати також, що всі питання організації військово-медичної освіти узгоджувались з першим начальником військово-медичної служби ЗС України генералмайором медичної служби Г.В. Циганком. Думаю, що ми маємо гордитися їх прозорливістю та професіоналізмом, адже вони із самого початку діяльності вищого військово-медичного навчального закладу визначилися 3 правильними назвами кафедр i дисциплін, які відповідають сучасним уявленням щодо їх місця серед медичних наук та їх історичного генезу.

I наприкінці, якщо словосполучення «воєнно-польова» було вже застарілим для B.A. Оппеля і С.С. Юдіна майже 100 років назад, якщо М.I. Пирогов, який запропонував цей термін, сам його не вживав, якщо головний терапет Червоної армії М.С. Вовсі , головні терапевти фронтів, армійські терапевти Другої світової війни майже не користувалися ним, якщо засновник російської клінічної медицини М.Я. Мудров майже 300 років назад говорив про «військову терапію», а наш видатний земляк А. Чаруковський тоді ж говорив про «хвороби армії», а як нам бути з майбутніми партнерами по НАТО, якщо у них, та взагалі ніде у світі, більше не викорисовується термін «воєнно-польова» і не має воєнно-польової хірургії та воєнно-польової терапії, крім деяких бувших республік СРСР та країн його сателітів, які його собі присвоїли та «зрадянщили», то чи стоїть нам повертатись до колишніх назв, та дисциплін, які не існують? А своє захоплення генієм M.I. Пирогова і повагу до його особистості будемо виражати не у збережені терміну «воєнно-польова», а в іншому - у подальшому розвитку військової хірургії і військової терапії.

\section{Література}

1.Пирогов Н. Начала общей военно-полевой хирургии взятые из наблюдений военногоспитальной практики и воспоминаний о Крымской войне и Кавказской экспедиции. Часть 1. - М.-Л., 1941. - с. 4.

2.Пирогов Н.Военно-врачебное дело и частная помощь на театре войны в Болгарии и в тылу действующей армии в 1877-1878 гг. - С.-Пб., 1879. - 382 с.

3.Юдин С.С. Образы прошлого и силуэты некоторых военно-полевых хирургов. - М., 1944. - с. 612.

4.Борнгаупт Ф.К. Очерк развития хирургии за XIX столетие//Университетские известия. - 1899. № 11. - c. 4 .

5.Протоколы заседаний Совета Университета Св.Владимира//Университетские известия. - 1863. - № 9. - с. 6, 14,-15, 31-32.

6.Обозрение преподавания в Императорском Университете Св.Владимира//Университетские известия. - 1864. - № 12. - с. 62.

7.Хроника//Медицинский вестник - 1869. - № 39. - с. 342.

8.Оппель В.А. История русской хирургии. Критический очерк. В 2-х частях. - Вологда, 1923. - с. 229-230.

9.Оппель В.О. Очерки хирургии войны. - Л., 1940. - с. 15-17.

10.Заметки по военно-полевой хирургии. Под редакцией С.С.Юдина. - М., 1943. - с. 3-5.

11.Вовси М.С. Внутренняя медицина в период Великой отечественной войны 1941-1945 гг. В кн: Труды 13 Всесоюзного съезда терапевтов 15-20 июня 1947 г. Гл. ред. Г.Ф.Ланг. - Л., 1947. - с. 18-29.

12.Бадылькес С.О. Выступления в прениях. - Там же. - с. 32-34.

13.Энциклопедический словарь военной медицины. Гл. ред. Е.И.Смирнов. Том 5. - М., 1948. - с. 465-466.

14.Мудров М.Я. Слово о пользе и предметах военной гигиены. У кн.: М.Я.Мудров. Избранные произведения . - М., 1949. - с.161-162.

15.Крестовский П. Материалы к истории кафедры частной патологии и терапии Императорской Военно-медицинской академии (1798-1898 гг.). Дисс. на степ. доктора медицины. С.-П., 1898. - с. 46-61.

16.Чаруковский Я. Военно-походная медицина. В 5 частях. - С-Пб., 1836-1837. - 417 с.

17.Верба А.В., Жаховський В.О., Лівінський В.Г. Медичне забезпечення Збройниз сил України: стан та погляди на перспективи розвитку. - К., 2017. - 82-104. 


\section{References}

1.Pirogov N. (1941) Nachala obshchei voenno-polevoi khirurgii vzyatye iz nablyudenii voennogospital'noi praktiki i vospominanii o Krymskoi voine i Kavkazskoi ehkspeditsii [The beginnings of general field surgery taken from observations of military hospital practice and memories of the Crimean War and the Caucasian expedition]. [in Russian].

2. Pirogov N. (1879) Voenno-vrachebnoe delo i chastnaya pomoshch' na teatre voiny v Bolgarii i v tylu deistvuyushchei armii v 1877-1878 gg. [Medical medicine and private assistance at the theater of war in Bulgaria and in the rear of the army in 1877-1878]. 382. [in Russian].

3. Yudin S.S. (1944) Obrazy proshlogo i siluehty nekotorykh voenno-polevykh khirurgov [Images of the past and silhouettes of some field surgeons]. 6-12.

4. Borngaupt F.K. (1899) Ocherk razvitiya khirurgii za XIX stoletie [Essay on the development of surgery for the 19th century] Universitetskie izvestiya. № 11. [in Russian].

5. (1863) Protokoly zasedanii Soveta Universiteta Sv.Vladimira [Minutes of meetings of the Council of the University of St. Vladimir] Universitetskie izvestiya. № 9. [in Russian].

6. (1864) Obozrenie prepodavaniya v Imperatorskom Universitete Sv.Vladimira [Teaching Overview at Imperial University of St. Vladimir] Universitetskie izvestiya. № 12. [in Russian].

7. (1869) Khronika [Chronicle] Meditsinskii vestnik. № 39. [in Russian].

8. Oppel' V.A. (1923) Istoriya russkoi khirurgii [History of Russian surgery] Kriticheskii ocherk. [in Russian].

9. Oppel' V.O. (1940) Ocherki khirurgii voiny [Essays on Surgery of War]. [in Russian].

10. Pod redaktsiei S.S.Yudina (1943) Zametki po voenno-polevoi khirurgii [Field Surgery Notes], M. [in Russian].

11. Vovsi M.S. (1947) Vnutrennyaya meditsina v period Velikoi otechestvennoi voiny 1941-1945 gg. [Internal medicine during the Great Patriotic War of 1941-1945] V kn: Trudy 13 Vsesoyuznogo s"ezda terapevtov 15-20 iyunya 1947 g. Gl. red. G.F.Lang. L. [in Russian].

12. Badyl'kes S.O. (1947) Vystupleniya $\mathrm{v}$ preniyakh [Speeches in the debate] V kn: Trudy 13 Vsesoyuznogo s"ezda terapevtov 15-20 iyunya 1947 g. Gl. red. G.F.Lang. L. [in Russian].

13. Gl. red. E.I.Smirnov (1948) Ehntsiklopedicheskii slovar' voennoi meditsiny [Encyclopedic Dictionary of Military Medicine] Tom 5, M. [in Russian].

14. Mudrov M.Ya. (1949) Slovo o pol'ze i predmetakh voennoi gigieny [A word about the benefits and items of military hygiene] Izbrannye proizvedeniya. [in Russian].

15. Krestovskii P. (1898) Materialy k istorii kafedry chastnoi patologii i terapii Imperatorskoi Voennomeditsinskoi akademii (1798-1898 gg.) [Materials for the history of the Department of Private Pathology and Therapy of the Imperial Military Medical Academy (1798-1898)] Diss. na step. doktora meditsiny. S.-P. [in Russian].

16. Charukovskii Ya. (1836-1837) Voenno-pokhodnaya meditsina [Military field medicine] V 5 chastyakh. S-Pb. [in Russian].

17. Verba A.V., Zhakhovs'kii V.O., Livins'kii V.G. (2017) Medichne zabezpechennya Zbroiniz sil Ukraïni: stan ta poglyadi na perspektivi rozvitku [Medical care Zbroyniz forces of Ukraine: Stan and look at the prospect of development] K. [in Ukraine].

\section{ВОЕННО-ПОЛЕВАЯ ТЕРАПИЯ ИЛИ ВОЕННАЯ ТЕРАПИЯ, ВОЕННО-ПОЛЕВАЯ ХИРУРГИЯ ИЛИ ВОЕННАЯ ХИРУРГИЯ?}

\section{М.П. Бойчак}

Украинская военно-медицинская академия, г. Киев

Введение. В статье в дискуссионной форме рассматриваются вопросы относительно названий кафедр военной терапии и военной хирургии Украинской военно-медицинской академии $и$ соответствующих дисциплин, изучаемые на этих кафедрах. В историческом аспекте исследуется эволюция взглядов относительно этих названий (военно-полевая хирургия - военная хирургия, военнополевая терапия - военная терапия), начиная от М.И. Пирогова, В.А. Оппель, С.С. Юдина, заканчивая формированием соответствующих кафедр и учебных дисциплин при организации Украинской военномедицинской академии.

Цель. Рассмотреть вопрос относительно названий кафедр военной терапии и военной хирургии Украинской военно-медицинской академии и соответствующих дисциплин, изучаемые на этих кафедрах.

Материалы и методы. В исследовании использованы исторический и бібліосемантичний методы для полного раскрытия сущности изучаемых понятий. 
Результаты. Оба термина «Военно-полевая терапия» и «Военная терапия» имеют право на существование, использовались в разные времена по разному. Как на нас, то более правильно, сегодня, учитывая названия кафедры, названия дисциплины, использовать термин “Военная терапия», ведь на кафедре, кроме классической военно-полевой терапии (поражение ионизирующим излучением, поражения отравляющими веществами, биологическими факторами и тому подобное) изучаются еще много других дисциплин: 24 дисциплины для слушателей факультета подготовки военных врачей; 23 дисциплины для факультета переподготовки и повышения квалификации (специализация, тематическое усовершенствование, до 2020 года предаттестационные циклы) и 12 дисциплин для медицинских сестер (специализация, тематическое усовершенствование). Кроме военных дисциплин на кафедре ВТ преподаются «мирные» дисциплины: кардиология, пульмонология, гастроэнтерология, гематология, ревматология, психиатрия и наркология, психотерапия, физиотерапия, лабораторная диагностика, функциональная диагностика и прочее. То есть термин «Военная терапия» имеет более широкое толкование, чем термин «Военно-полевая терапия».

Выводы. Подытоживая рассмотренный вопрос, надо отдать должное руководителям военной медищины, которые при формировании Военно-медицинского отделения при Украинском государственном медицинском университете имени А.А. Богомольца (позже УВМА) и профильных кафедр, назвали их соответственно кафедрами военной хирургии и военной терапии. Если словосочетание «военно-полевая» было уже устаревшим для.А. Оппель и С.С. Юдина почти 100 лет назад, если М.И.Пирогов, предложивший этот термин, сам не употреблял, если главный терапет Красной армии М.С. Вовси, главные терапевты фронтов, армейские терапевты Второй мировой войны почти не пользовались им, если основатель российской клинической медицины М.Я. Мудров почти 300 лет назад говорил о «военную терапию», а наш выдающийся земляк А. Чаруковський тогда же говорил о «болезни армии», а как нам быть с будущими партнерами по НАТО, если у них, и вообще нигде в мире больще не викорисовуеться термин «военнополевая» и не военно-полевой хирургии и военно-полевой терапии, кроме некоторых бывших республик СССР и стран его сателлитов, которые его себе присвоили и «зрадянщилы», то стоит нам возвращаться к прежним названиям, и дисциплин, которые не существуют? А свое восхищение гением М.И. Пирогова и уважение к его личности будем выражать не у сохранены термина «военно-полевая», а в другом - в дальнейшем развитии военной хирургии и военной терапии.

Ключевые слова: военно-полевая-хирургия, военно-полевая терапия, военная хирургия, военная терапия, Украинская военно-медицинская академия.

\title{
BATTLE-FIELD THERAPY OR MILITARY THERAPY, BATTLE-FIELD SURGERY OR MILITARY SURGERY?
}

\author{
M.P. Boychak
}

Ukrainian military medical Academy, Kyiv

Introduction. The article in discussion form addresses issues regarding names of military departments of therapy and military surgery Ukrainian military medical Academy and of the relevant disciplines in these departments. In the historical aspect of the evolution of views on these names (of military field surgery, military surgery, military-field therapy military therapy), ranging from M. I. Pirogov, V. A. Oppel, S. S. Yudina, ending with the formation of the relevant departments and disciplines in the organization of the Ukrainian military-medical Academy.

Purpose of the study. To consider the issue regarding names of military departments of therapy and military surgery Ukrainian military medical Academy and of the relevant disciplines in these departments.

Materials and methods. The study used historical and bamoueni methods for full disclosure of essence of the studied concepts.

Results. Both the term "Military-field therapy, and Military therapy" have the right to exist, has been used at different times in different ways. As for us, it is more correct today, given the name of the Department name of discipline, to use the term "Military treatment", because the Department, in addition to the classic military field therapy (lesion of ionizing radiation, destruction of toxic substances, biological factors, and the like) are studied in many other disciplines: 24 discipline for students of the faculty for training military doctors; 23 discipline for the faculty of retraining and further training (specialization, thematic improvement, by 2020, pre-cycles) and 12 subjects for nursing (specialization, thematic improvement). In addition to the military courses in the Department $W$ are taught the "peaceful" discipline: cardiology, pulmonology, gastroenterology, Hematology, rheumatology, psychiatry and narcology, psychotherapy, physiotherapy, laboratory diagnostics, functional diagnostics, and more. That is, the term "Military treatment" is broader than the term "Military-field therapy".

Conclusions. Summing up considered, it is necessary to pay tribute to the leaders of military medicine in the formation of Military-medical Department at Ukrainian state medical University named after Bogomolets (later UWMA) and specialized departments, called their respective departments of military surgery and military therapy. If the phrase "military field" was already deprecated.And. Oppel and S. S. Yudin almost 100 years ago, if M. I.Pirogov, 
who proposed this term, did not use it himself, if the chief therapist of the Red Army MS At all, the chief therapists of the fronts, army therapists of the Second World War almost did not use it, if the founder of Russian clinical medicine M.Ya. Mudrov spoke about "military therapy" almost 300 years ago, and our prominent compatriot A. Charukovsky at the same time spoke about "diseases of the army", and how can we be with future NATO partners, if they, and nowhere else in the world, no longer the term "military-field" is used and has no military-field surgery and militaryfield therapy, except for some former republics of the USSR and the countries of its satellites, which appropriated and "betrayed" it, whether we should return to the former names and disciplines. that do not exist? And his admiration for the genius of MI Pirogov and respect for his personality will be expressed not in the preserved term "military field", but in another - in the further development of military surgery and military therapy.

Key words: battle-field surgery, battle-field therapy, military surgery, military therapy, Ukrainian Military Medical Academy.

\section{Відомості про авторів:}

Бойчак М.П., генерал-майор медичної служби у відставці, доктор медичних наук, професор кафедри військової терапії Української військово-медичної академії, ORCID ID 0000-0002-8289-6239

\section{Сведения об авторах:}

Бойчак М.П., генерал-майор медицинской службы в отставке, доктор медицинских наук, професор кафедры военной терапии Украинской военно-медицинской академии, ORCID ID 0000-00028289-6239

\section{Information about authors:}

Boychak M.P., Major-general of MS, retired, DM DSc, Proff., professor of military therapy department at Ukrainian Military-Medical Academy, ORCID ID 0000-0002-8289-6239 